Article

\title{
Genotoxic Effects of Aluminum Chloride and Their Relationship with N-Nitroso-N-Methylurea (NMU)-Induced Breast Cancer in Sprague Dawley Rats
}

\author{
Alejandro Monserrat García-Alegría 1,2,*(D), Agustín Gómez-Álvarez ${ }^{3}$, Iván Anduro-Corona ${ }^{4}$, \\ Armando Burgos-Hernández ${ }^{5}$, Eduardo Ruíz-Bustos ${ }^{1,2}$, Rafael Canett-Romero ${ }^{5}$, \\ Humberto González-Ríos ${ }^{4}$, José Guillermo López-Cervantes ${ }^{6}$, \\ Karen Lillian Rodríguez-Martínez ${ }^{7}$ (D) and Humberto Astiazaran-Garcia ${ }^{1,2,4, *(D)}$ \\ 1 Programa de Doctorado en Ciencias Químico Biológicas y de la Salud, Universidad de Sonora, \\ 83000 Hermosillo, Sonora, Mexico; eduardo.ruiz@unison.mx \\ 2 Departamento de Ciencias Químico Biológicas, Universidad de Sonora, 83000 Hermosillo, Sonora, Mexico \\ 3 Departamento de Ingeniería Química y Metalurgia, Universidad de Sonora, 83000 Hermosillo, Sonora, \\ Mexico; agustin.gomez@unison.mx \\ 4 Centro de Investigación en Alimentación y Desarrollo, AC, 83304 Hermosillo, Sonora, Mexico; \\ ivan.anduro@ciad.mx (I.A.-C.); hugory@ciad.mx (H.G.-R.) \\ 5 Departamento de Investigación y Posgrado en Alimentos, Universidad de Sonora, 83000 Hermosillo, Sonora, \\ Mexico; armando.burgos@unison.mx (A.B.-H.); rafacanett@gmail.com (R.C.-R.) \\ 6 Departamento de Medicina y Ciencias de la Salud, Universidad de Sonora, 83000 Hermosillo, Sonora, \\ Mexico; guillermo.lopez@unison.mx \\ 7 Licenciatura en Nutrición Humana, Universidad Estatal de Sonora, Unidad Académica Hermosillo, \\ 83100 Hermosillo, Sonora, Mexico; karenroma.ues@gmail.com \\ * Correspondence: monserrat.garcia@unison.mx (A.M.G.-A.); hastiazaran@ciad.mx (H.A.-G.); \\ Tel.: +52-662-2592163(A.M.G.-A.); +52-662-2892400 (H.A.-G.)
}

Received: 4 March 2020; Accepted: 14 April 2020; Published: 20 April 2020

check for updates

\begin{abstract}
Recently, soluble forms of aluminum for human use or consumption have been determined to be potentially toxic due to their association with hepatic, neurological, hematological, neoplastic, and bone conditions. This study aims to assess the genotoxic effect of aluminum chloride on genomic instability associated with the onset of N-nitroso-N-methylurea (NMU)-induced breast cancer in Sprague Dawley rats. The dietary behavior of the rats was assessed, and the concentration of aluminum in the mammary glands was determined using atomic absorption spectroscopy. Genomic instability was determined in the histological sections of mammary glands stained with hematoxylin and eosin. Moreover, micronucleus in peripheral blood and comet assays were performed. The results of dietary behavior evaluation indicated no significant differences between the experimental treatments. However, aluminum concentration in breast tissues was high in the +2000Al/-NMU treatment. This experimental treatment caused moderate intraductal cell proliferation, lymph node hyperplasia, and serous gland adenoma. Furthermore, micronucleus and comet test results revealed that $+2000 \mathrm{Al} /-\mathrm{NMU}$ led to a genotoxic effect after a 10-day exposure and the damage was more evident after a 15-day exposure. Therefore, in conclusion, genomic instability is present and the experimental conditions assessed are not associated with breast cancer.
\end{abstract}

Keywords: genotoxicity; aluminum chloride; rats 


\section{Introduction}

Aside from the multiple industrial applications of aluminum, it has applications in different fields including a few uses related to human consumption such as a flocculant in drinking water purification processes, as an adjuvant in vaccine preparation, and as an additive in beverages, foods (e.g., sweets and cheeses), antiperspirants and deodorants, among others [1-7]. However, the soluble forms of aluminum are considered potentially toxic because of their high water solubility and genotoxic capacity and because of our exposure to these soluble forms at subacute and chronic levels on a daily basis $[6,8,9]$. Recent estimates from the United States denote that middle-class young adults consume an average of 105-150 mg of aluminum per day in food and drinks, indicating that individuals are constantly exposed to the frequent use or consumption of different forms of aluminum [4,5,10]. Genomic instability is an essential prerequisite for the generation of multiple carcinogenesis-related alterations and mutations [11,12]. Therefore, trace (essential) elements, metals, and heavy metals are associated with breast cancer [13-16] either because cancer decreases the levels of some trace metals or because the metals cause or are associated with the genesis of cancer [2,17]. One of these trace metals is arsenic, which is associated with genomic instability, lung cancer [18], and deficient manganese metabolism, causing mitotic deregulation associated with genomic instability in humans [19]. Iron, another trace metal, is also associated with the development of genomic instability and liver, lung, and intestinal cancers in experimental rats [20]. Moreover, copper has reportedly been linked to genomic instability, which is related to breast cancer in rats [21], whereas cadmium is related to breast cancer in women worldwide [22]. Furthermore, aluminum chloride is being investigated for its potential relationship with neurological, hepatic, bone, and hematological conditions as well as with breast cancer [23-27]. Therefore, we assessed the genotoxic effects of aluminum concentration in Sprague Dawley rats and determined whether a link could be established with N-nitroso-N-methylurea (NMU)-induced breast cancer. This will aid in the development of new strategies for addressing exposure due to the use and/or consumption of soluble forms of aluminum as well as in the elucidation of their genotoxic hazards and relationship with the genesis of breast cancer in humans.

\section{Materials and Methods}

\subsection{Chemicals}

NMU N1517-1G (lot no. SLBF6813V) reagent was purchased from Sigma Chemical Co. (St. Louis, MO, USA), TRIzol ${ }^{\mathrm{TM}}$ reagent was acquired from Life Technologies (Thermo Fisher Scientific, cat. no. 1596026, (Waltham, MA, USA), and the QuantiTect Reverse Transcription Kit manufactured by Qiagen (cat. no. 205311), (Germantown, MD, USA) was obtained. In addition, the TaqMan gene expression assays were purchased from Applied Biosystems (cat. nos. 4331182 and 4308313), and aluminum chloride $\left(\mathrm{AlCl}_{3}\right)$ was procured from Sigma Chemical Co. (St. Louis, MO, USA). All other chemical products were of analytical grade.

\subsection{Experimental Animals}

We selected 32 female Sprague Dawley rats (weight between 180 and $220 \mathrm{~g}$ ) from the biotery at the Food Sciences Graduate Studies and Research Department at the University of Sonora.

\subsection{Experimental Design (Treatments)}

Groups of eight rats were randomly assigned to one of the following experimental treatments: treatment $\mathrm{A}$ rats not fed with aluminum and with no breast cancer induction (negative control) (-Al/-NMU); treatment $\mathrm{B}$ rats fed with $2000 \mathrm{mg} / \mathrm{L}$ aluminum $\left(\mathrm{AlCl}_{3}\right)$ and breast cancer induced by NMU (+2000Al/+NMU); treatment C rats fed with $2000 \mathrm{mg} / \mathrm{L}$ aluminum $\left(\mathrm{AlCl}_{3}\right)$ with no breast cancer induction (+2000Al/-NMU); and treatment $\mathrm{D}$ rats not fed with aluminum and breast cancer induced by NMU (positive control) (-Al/+NMU). Rats not fed with aluminum $\left(\mathrm{AlCl}_{3}\right)$ and with no breast cancer induction (NMU) were treated with $0.98 \%$ physiological saline to match the experimental 
conditions. Rats were intragastrically (gavage) fed $1 \mathrm{~mL} \mathrm{AlCl} 3$ days/week for 90 days, whereas NMU was intraperitoneally administered at 50 and 70 days of age [28,29]. A volume of $1 \mathrm{~mL}$ of $\mathrm{AlCl}_{3}$ solution with a concentration of $2000 \mathrm{mg} / \mathrm{L}$ is equivalent to administering $2 \mathrm{mg}$ of aluminum to rats, considering that the mean weight of rats is $0.2 \mathrm{~kg}$. This is equivalent to a dose of $10 \mathrm{mg} \mathrm{Al} / \mathrm{day} / \mathrm{kg}$ of body weight.

\subsection{Breast Cancer Induction in Rats}

The rats were treated with NMU (N1517-1G Sigma-Aldrich, St. Louis, MO, USA) at doses of $50 \mathrm{mg} / \mathrm{kg}$ of body weight administered at 50 and 70 days of age to induce breast adenocarcinoma [30,31].

\subsection{Biotery Handling Conditions}

Biotery handling conditions were as follows: $12 \mathrm{~h}$ light/dark cycles, humidity ranging from $40 \%$ to $70 \%$, temperature between $18{ }^{\circ} \mathrm{C}$ and $22{ }^{\circ} \mathrm{C}$, and ad libitum access to water and food [32].

\subsection{Diet}

Baseline pellet diet containing $23 \%$ protein, $1 \%$ vitamins, $4 \%$ minerals, $4 \%$ fiber, $6.5 \%$ fat, $0.2 \%$ choline bitartrate, $0.2 \%$ methionine, other minor dietary components, and starch to make up to a total of $100 \%$, was used. Maximum humidity was $12 \%$. This rat-feed was manufactured by LabDiet, Fort Worth, TX, USA, and marketed by PetFood of México [33].

\subsection{Sampling}

\subsubsection{Breast Tissue Samples}

Samples were obtained via surgical cuts of the mammary gland of rats anesthetized in a halothane chamber and then euthanized by cervical dislocation to avoid animal suffering, as per the NOM-033-ZOO-1995 and NOM-062-ZOO-1999 Official Mexican Standards, European Medicines Agency (EMEA, Amsterdam, The Netherlands, 2009), and Food and Drug Administration (FDA, Silver Spring, MD, USA, 2014) [34-37]. After quantifying the aluminum concentration, the samples were used for histopathological evaluation and total RNA extraction to evaluate the genetic expression of BRCA1 and SCL11a2.

\subsubsection{Blood Samples}

For genotoxicity evaluation, blood was obtained from a tail cut for micronucleus (MN) analysis and individual cells (comet assay) via alkaline electrophoresis.

\subsection{Determination of Aluminum Concentration in Breast Tissues}

Samples were previously digested in a TITAN MPS microwave oven [38]. Briefly, $0.4 \pm 0.02 \mathrm{~g}$ of breast tissue was weighed and placed in $15 \times 2.5 \mathrm{~cm}$ Teflon digestion tubes containing $7 \mathrm{~mL}$ of concentrated nitric acid $\left(\mathrm{HNO}_{3}\right)$. The digestion conditions were $200{ }^{\circ} \mathrm{C}, 35 \times 10^{5} \mathrm{~Pa}$, and $1600 \mathrm{~W}$ for $47 \mathrm{~min}$ [39]. The resultant acidic residue was made to a total of $100 \mathrm{~mL}$ using deionized water for the subsequent quantification of aluminum concentration.

The determination of aluminum concentration in the standard, certified reference material, and rat breast tissue was performed using atomic absorption spectroscopy with an AAnalyst 400 automated equipment in a graphite furnace absorption atomic spectroscopy (GFAAS) or in the electrothermal absorption atomic spectroscopy (ETAAS) mode, under the operating conditions recommended by the manufacturer $[40,41]$. The analytical method was previously optimized and its expanded uncertainty for quantifying aluminum by FAAS (flame absorption atomic spectroscopy) and ETAAS was subsequently validated and estimated uncertainty [42-44]. 


\subsection{Evaluation of Genomic Instability}

\subsubsection{Histopathological Evaluation}

Morphological instability was assessed by preparing histological cuts from rat mammary glands and mounting them on fixed slides using a microtome. The preparations were stained with hematoxylin and eosin and observed under a LEICA DME optical microscope under 40× and 100× magnification [45].

\subsubsection{Micronucleus Analysis}

To examine MN, three female Sprague Dawley rats weighing $200 \pm 20 \mathrm{~g}$ were used per treatment group. Peripheral blood sampling was performed according to the present regulations [34,37] at 5, 10, and 15 days of experimental treatment. Briefly, $0.5 \mathrm{~mL}$ of peripheral blood was collected in 1.5-mL Eppendorf tubes and three blood smears (extensions) were prepared on clean slides with blood from each rat. The smears were stained with Wright's stain [46] and MN were subsequently counted in 2000 erythrocytes (1 MN, $2 \mathrm{MN}$, or >2 MN) [28] under a LEICA DME compound microscope (Buffalo, NY, 14240, USA).

\subsubsection{Alkaline Electrophoresis Test in Individual Cells (Comet Assay)}

Cell viability was assessed using trypan blue dye, and cells were counted in a Neubauer chamber/hematocytometer [47,48]. The comet test was performed according to Singh's method [49] at an exploratory level. Briefly, we used three female Sprague Dawley rats from treatments $\mathrm{A}(-\mathrm{Al} /-\mathrm{NMU})$ and C (+2000Al/-NMU), which were anesthetized in a halothane chamber, to extract 3-4 mL of blood by intracardiac puncture, and these rats were subsequently euthanized by cervical dislocation. A total of $30 \mu \mathrm{L}$ of whole blood was added to $300 \mu \mathrm{L}$ of $1 \%$ low melting point agarose at $37{ }^{\circ} \mathrm{C}$. A total of $75 \mu \mathrm{L}$ of this mixture was extracted and placed on a slide pre-coated with a $150-\mu \mathrm{L}$ layer of $1 \%$ regular agarose, which was immediately covered with a coverslip and maintained at $4{ }^{\circ} \mathrm{C}$ for $10 \mathrm{~min}$. The coverslip was removed and $75 \mu \mathrm{L}$ of $1 \%$ low melting point agarose was added at $37^{\circ} \mathrm{C}$ to create another layer and form a sandwich, which was protected with a coverslip and maintained at $4{ }^{\circ} \mathrm{C}$ for $10 \mathrm{~min}$. The cells were subsequently lysed in a lysis solution $(2.5 \mathrm{mM} \mathrm{NaCl}, 1 \% \mathrm{KOH}, 100 \mathrm{mM}$ EDTA, $10 \mathrm{mM}$ Trizma base, $1 \%$ Triton X-100, and 10\% DMSO) for $1 \mathrm{~h}$ at $4{ }^{\circ} \mathrm{C}$. The samples were then placed in a dark electrophoresis chamber containing cold, alkaline running buffer at $\mathrm{pH}>13(300 \mathrm{mM} \mathrm{NaOH}$, $1 \mathrm{nM}$ EDTA, $\mathrm{pH}$ adjusted to >13). Samples were stored in the refrigerator for $20 \mathrm{~min}$. The conditions of the electrophoretic run were $25 \mathrm{mV}$ and $300 \mathrm{~mA}$ for $20 \mathrm{~min}$.

Following electrophoresis, the slides were removed and washed three times with a neutralization buffer (0.4 mM Tris buffer adjusted to $\mathrm{pH} 7.5)$ for $5 \mathrm{~min} /$ wash. Finally, the slides were washed twice with anhydrous absolute ethanol for $5 \mathrm{~min} /$ wash. Excess alcohol was removed, and the slides were allowed to dry, following which they were then stained with $25 \mu \mathrm{L}$ ethidium bromide $(20 \mu \mathrm{g} / \mathrm{mL}$ in deionized water) and covered with coverslips. All stages of the comet assay were performed under indirect yellow light or in the dark. Comet observations were made under a LEICA DM2500 fluorescence microscope equipped with an excitation filter (515-560 nm) and barrier filter (590 nm). Photographs were captured with a 5-megapixel LEICA model DFC450C digital camera cooled with monochromatic light, with a C-mount adapter. The comet evaluations were performed using the TriTek CometScore software. DNA damage was reported as \% Olive Tail Moment (\% OTM) [50,51].

\subsubsection{Genetic Expression Assay Using RT-qPCR}

Chomczynski and Sacchi's method (1987) [52] was used for total RNA extraction. The mammary gland tissues $(0.050 \pm 0.008 \mathrm{~g})$ collected from the rats was weighed and used for total RNA extraction using TRIzol. In addition, PolyTron equipment was used to homogenize the samples. Purity and concentration of the total RNA obtained was estimated by absorbance at 260/280 nm using Nanodrop equipment [53], and the integrity was determined by electrophoresis in $1.5 \%$ agarose gel under denaturing conditions and then stained with $1.5 \%$ ethidium bromide according to Jacobs Protocol 
(2017) [54]. A reverse transcription reaction was performed with the RNA obtained from each sample using a QuantiTect Reverse Transcription kit to obtain the cDNA, under the operating conditions recommended by the provider (Qiagen, 2016; cat. no. 205311). PCR reactions were conducted in a T100 Thermocycler (BioRad, 2015, Hercules, CA, USA).

On obtaining the cDNA, genetic expressions of BRCA1 and SCL11a2 (FAM fluorophore) were evaluated using $30 \mathrm{ng}$ of cDNA and TaqMan genetic expression assay (Applied Biosystems). RT-qPCR reactions were conducted in the StepOneTM v2.3 device using GAPDH (VIC fluorophore) as the reference gene (housekeeping gene). Duplex reactions (BRCA1/GAPDH and SCL11a2/GAPDH) were performed under the conditions recommended by the provider (Applied Biosystems 2016).

\subsection{Statistical Analysis}

The Kolmogorov-Smirnov test was applied to verify normality of aluminum concentrations in the mammary gland tissues; when these assumptions were not met, the data were analyzed using the Kruskal-Wallis test. Data for the variables that fulfilled the normality assumptions were assessed using one-way analysis of variance using the General Linear Model procedure (GLM ANOVA), where the experimental treatments was the main effect. Regarding the number of MNs, only counts obtained for cells with a single $\mathrm{MN}$ were used because no records were available for cells with $\geq 2 \mathrm{MNs}$. MN and genotoxicity data were analyzed using GLM ANOVA for a complete block random design. The model included the fixed effects of treatments and sampling times (blocks). Any differences observed between the means were analyzed using the Tukey-Kramer multiple comparison test. Statistical significance was considered at a 0.05 probability for type I error $(p<0.05)$. All data were processed using the NCSS statistical package, version 2007 (Kaysville, UT, USA) The research project was approved by the Commission of Bioethics in Research of the University of Sonora, ex officio CBI-UNISON 1/2015 (Approval date: 9 February 2015).

\section{Results}

\subsection{Determining Aluminum Concentration in Breast Tissue}

Table 1 denotes a significant difference $(\alpha=0.05)$ between the $+2000 \mathrm{Al} /-\mathrm{NMU}$ treatment and the other experimental treatments, with a value of $38.17 \pm 2.49 \mu \mathrm{g}$ of aluminum/g of mammary gland tissue.

Table 1. Concentration of aluminum (median of $\mu \mathrm{g} \mathrm{Al} / \mathrm{g}$ of tissue) in the mammary gland of Sprague Dawley rats quantified by graphite furnace absorption atomic spectroscopy (GFAAS).

\begin{tabular}{|c|c|c|c|c|c|}
\hline \multicolumn{6}{|c|}{ TREATMENTS * } \\
\hline Variables & $-\mathrm{Al} /-\mathrm{NMU}$ & $+2000 \mathrm{Al} /+\mathrm{NMU}$ & $+2000 \mathrm{Al} /-\mathrm{NMU}$ & $-\mathrm{Al} /+\mathrm{NMU}$ & $p$ Value $* *$ \\
\hline $\mathrm{n}$ & 8 & 8 & 8 & 7 & \\
\hline Mammary gland tissue & $11.395^{\mathrm{a}}$ & $12.288^{\mathrm{a}}$ & $38.17^{b}$ & $17.929^{a}$ & 0.0001 \\
\hline
\end{tabular}

\subsection{Evaluation of Genomic Instability}

\subsubsection{Histopathological Evaluation}

Histopathological results (Figure 1) showed that the effect of the treatments corresponded to hyperplasia and that there was no evidence of cancer development, similar to the results obtained by some researchers $[45,55,56]$. 

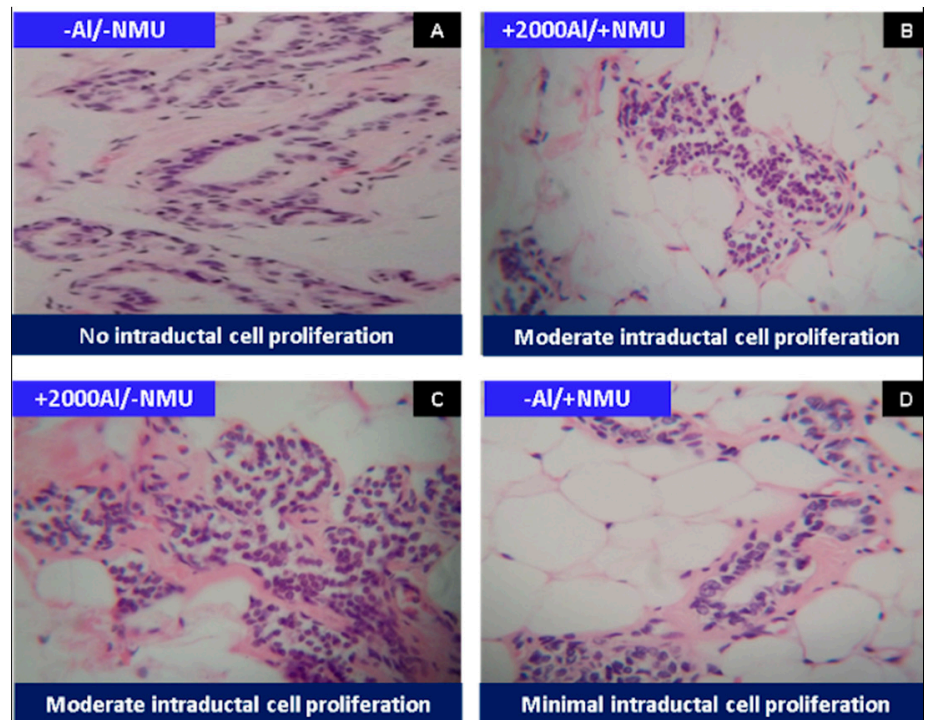

Figure 1. The histological change found in the breast tissue of Sprague Dawley rats is shown with the different treatments used. Hyperplasia of the breast ducts was minimal (D) to moderate $(\mathbf{B}, \mathbf{C})$. Normal/negative control (A). HEx400.

\subsubsection{Micronucleus Analysis}

$\mathrm{MN}$ analysis is a valuable indicator for the partial assessment of genotoxicity via ruptures in the chromosomes $[57,58]$. The complete MN count is shown in Table 2, which indicates that the presence of MNs was not detected in the negative control $(-\mathrm{Al} /-\mathrm{MNU})$ at 5,10 , or 15 days. This is normal to some extent because these rats were not administered aluminum solutions or NMU, a cancer inducing agent. As denoted in Figure 2, an effect from the treatment and exposure time $(p<0.05)$ was observed for counts with $1 \mathrm{MN}$. Our result suggests that there was no synergistic effect between aluminum $\left(\mathrm{AlCl}_{3}\right)$ and $\mathrm{NMU}$, as previously noted in the results obtained for aluminum concentration in the mammary glands as well as from the histological evaluation of the breast. In the $+2000 \mathrm{Al} /-\mathrm{NMU}$ and $-\mathrm{Al} /+\mathrm{NMU}$ treatments, a higher number of $\mathrm{MN}(p<0.05)$ were observed. Although the average number of $\mathrm{MN}$ was higher for the $+2000 \mathrm{Al} /-\mathrm{NMU}$ treatment than for the $-\mathrm{Al} /+\mathrm{NMU}$ treatment, there was no significant difference $(p>0.05)$ because of the substantial variance among the $+2000 \mathrm{Al} /-\mathrm{NMU}$ treatment replications. Nevertheless, the study proved that the treatment containing only aluminum could independently cause genotoxicity in rats.

Table 2. Genotoxicity caused by experimental treatments by micronucleus count (MN) in peripheral blood erythrocytes of female Sprague Dawley rats at 5, 10, and 15 days of exposure.

\begin{tabular}{|c|c|c|c|c|c|c|c|c|c|}
\hline \multirow{2}{*}{ Treatments } & \multicolumn{3}{|c|}{5 Days } & \multicolumn{3}{|c|}{10 Days } & \multicolumn{3}{|c|}{15 Days } \\
\hline & $1 \mathrm{MN}$ & $2 \mathrm{MN}$ & $>2 \mathrm{MN}$ & $1 \mathrm{MN}$ & $2 \mathrm{MN}$ & $>2 \mathrm{MN}$ & $1 \mathrm{MN}$ & $2 \mathrm{MN}$ & $>2 \mathrm{MN}$ \\
\hline (A) $-\mathrm{Al} /-\mathrm{NMU}$ & 0 & 0 & 0 & 0 & 0 & 0 & 0 & 0 & 0 \\
\hline (B) $+2000 \mathrm{Al} /+\mathrm{NMU}$ & 0 & 0 & 0 & 4 & 0 & 0 & 8 & 0 & 0 \\
\hline (C) $+2000 \mathrm{Al} /-\mathrm{NMU}$ & 0 & 0 & 0 & 9.3 & 0 & 0 & 28.6 & 2.6 & 0 \\
\hline (D) $-\mathrm{Al} /+\mathrm{NMU}$ & 1 & 0 & 0 & 8 & 0 & 0 & 18.6 & 0.6 & 0 \\
\hline
\end{tabular}




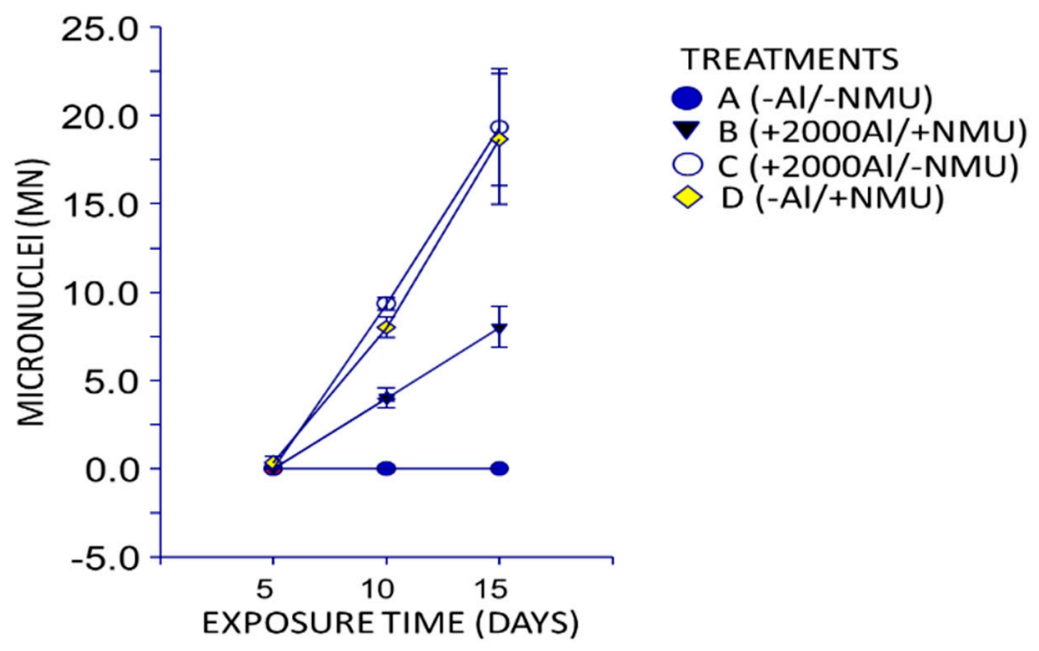

Figure 2. Genotoxicity (1 MN) caused by experimental treatments in the peripheral blood of Sprague Dawley rats at 5,10 , and 15 days of exposure.

In addition, the genotoxic effects started to significantly manifest $(p<0.05)$ on day 10 and showed greater values at day 15 (effect from exposure time), indicating a subacute effect due to aluminum bioconcentration. Additionally, the results revealed that the apparent effect was intermediate in treatments with aluminum and NMU $(+2000 \mathrm{Al} /+\mathrm{NMU})$.

\subsubsection{Alkaline Electrophoresis Test in Individual Cells (Comet Assay)}

The $96 \% \pm 2 \%$ cell viability identified by trypan blue was similar to the results obtained by other researchers $[47,48]$. This study was conducted at an exploratory level to determine whether the genotoxicity caused by aluminum in the form of $\mathrm{AlCl}_{3}$ caused DNA damage or fragmentation in rat leukocytes. Only three rats were used as a negative control (-Al/-NMU) and three rats were subjected to the $+2000 \mathrm{Al} /-\mathrm{NMU}$ experimental treatment, thereby proving that this experimental treatment could independently induce intraductal cell proliferation in mammary glands and lead to a higher number of comet and clouds as exposure time increased. Figure 3 denotes these results, indicating that there was no genotoxic damage at 5,10 , and 15 days of exposure after the $-\mathrm{Al} /-\mathrm{NMU}$ treatment (negative control). Conversely, no comets were observed in the $+2000 \mathrm{Al} /-\mathrm{NMU}$ experimental treatment, and only nucleoids or unrolled DNA were noted after five days of exposure. The test was consistent with the lack of genotoxicity observed in the formation of $\mathrm{MN}$ after five days of exposure. However, genotoxicity was distinctly observed after 10 and 15 days, when comets were observed. Although no significant differences $(\alpha=0.05)$ were observed in terms of the number of comets and \% OTM after 10 and 15 days of aluminum exposure, there were significant differences in terms of cloud formation because there were three and 73 clouds per 100 comets detected at 10 and 15 days of aluminum exposure, respectively.

\subsubsection{Genetic Expression Assay Using RT-qPCR}

The results of genetic expression obtained for BRCA1 and SCL11a2 using RT-qPCR indicate that no experimental evidence demonstrating the expression of both genes was present; therefore, it can be inferred that the product of $B R C A 1$ does not participate in the DNA damage repair mechanism as observed in the comet test. In addition, it can be determined that the product of SCL11a2 does not play a role in the aluminum transport process in Sprague Dawley rats under the proposed experimental conditions. 


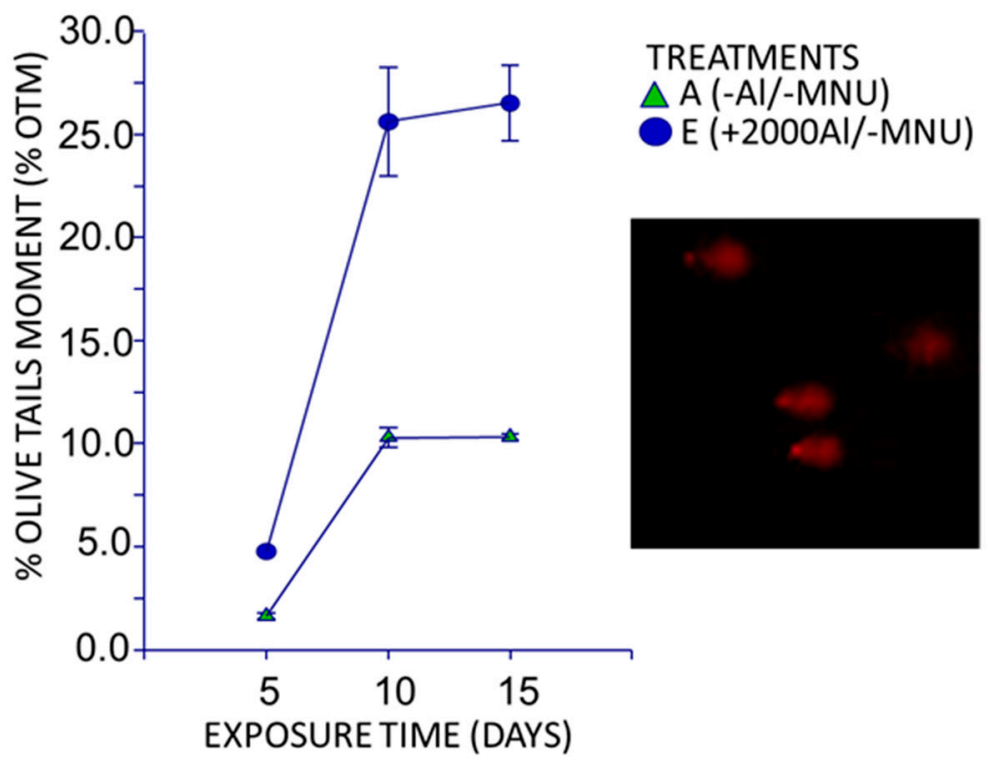

Figure 3. Genotoxic effect caused by the $+2000 \mathrm{Al} /-\mathrm{NMU}$ treatment in the peripheral blood of Sprague Dawley rats at 5,10 , and 15 days of exposure, evaluated by the comet test.

\section{Discussion}

\subsection{Determining Aluminum Concentration in Breast Tissue}

Oogoshi et al. (1994) reported that aluminum concentration was higher in the mammary glands of Sprague Dawley rats compared with other tissues by quantifying the concentration of various metals provided in their diet [59]. Furthermore, these results indicate that there was no synergistic effect of the treatments containing aluminum $\left(\mathrm{AlCl}_{3}\right)$ and $\mathrm{NMU}(+2000 \mathrm{Al} /+\mathrm{NMU})$; therefore, it can be assumed that, among the effects of NMU administration, tumorigenesis does not require aluminum as an essential microelement, or NMU leads to changes in the aluminum transportation mechanism. This effect has been observed when determining that NMU administration in rats modifies the ZnT-1 zinc transporter that causes failure in the zinc transportation mechanism $[60,61]$.

\subsection{Evaluation of Genomic Instability}

\subsubsection{Histopathological Evaluation}

NMU induces breast cancer in laboratory rats [62-67]. However, according to the present study, this compound caused only minimal cell proliferation in the ductal epithelium (-AL/+NMU). Reportedly, adenocarcinomas appeared 140 days after NMU application [68]. Cell proliferation of the ductal epithelium was not observed in treatment $\mathrm{A}(-\mathrm{Al} /-\mathrm{NMU})$, which was expected because this treatment represents the negative control. The most significant histopathological change caused by treatment $\mathrm{C}(+2000 \mathrm{Al} /-\mathrm{NMU})$ was ductal epithelial cell proliferation compared with the other treatments. A previous histopathological study showed that aluminum in the form of $\mathrm{AlCl}_{3}$ can cause liver damage in Sprague Dawley rats when orally administered for 30 days [57].

\subsubsection{Micronucleus Analysis}

The present study demonstrated that NMU generates MN after 10 days of exposure under the $+2000 \mathrm{Al} /-\mathrm{MNU}$ treatment. A previous study assessed the genotoxicity of aluminum using the MN test and reported that genotoxic agents such as cyclophosphamide generate $\mathrm{MN}$ in the peripheral blood of rats within $24 \mathrm{~h}$ [69]. On the other hand, Balasubramanyam et al. [28,70] determined that the intraperitoneally administered nanoparticles of $\mathrm{Al}_{2} \mathrm{O}_{3}$ caused an increase in liver $\mathrm{MN}$ counts in female Wistar rats. Moreover, they determined that increasing the dosages (500, 1000, or $2000 \mathrm{mg}$ of Al/kg 
of body weight) increased the number of MN when compared with the control group rats to which cyclophosphamide was administered as a genotoxic agent. This genotoxicity was corroborated by Klien and Godnić-Cvar [71]. Moreover, Türkez et al. [57,72,73] assessed liver genotoxicity caused by $\mathrm{AlCl}_{3}$ solutions in Sprague Dawley rats. They observed that a sub-chronic dose of $\mathrm{AlCl}_{3}$, intraperitoneally administered for 10 weeks increased the number of $\mathrm{MN}$; however, this effect can be reversed using boric acid or borax. Geyikoglu et al. [58] found that $\mathrm{AlCl}_{3}$ at a dose of $3 \mathrm{mg}$ of aluminum $/ \mathrm{kg}$ of body weight induced genotoxicity by forming $\mathrm{MN}$ in the hepatocytes of Sprague Dawley rats when aluminum was intraperitoneally administered for 10 weeks. In addition, Al-Obaidy et al. [74] demonstrated that 10,15 , and $25 \mathrm{mg}$ of $\mathrm{AlCl}_{3}$ solutions per $\mathrm{kg}$ of body weight intraperitoneally administered to male albino rats (Rattus norvegicus) increased the number of $\mathrm{MN}$ in the bone marrow, and the number of $\mathrm{MN}$ increased with the increase in dose. As the dose increased, the number of cells with MN decreased, and this decrease correlates with an increase in the number of cells that die due to apoptosis [75]. In the present study, we intragastrically (gavage) administered $\mathrm{AlCl}_{3}$ solutions and the genotoxic effect observed was similar to that of the intraperitoneally administered aluminum solutions, as previously reported $[73,74]$.

\subsubsection{Alkaline Electrophoresis Test in Individual Cells (Comet Assay)}

The results obtained in treatment $\mathrm{C}(+2000 \mathrm{Al} /-\mathrm{NMU})$ implies a greater genotoxic effect after 15 days of exposure that is irreversible and considerably greater than the effect of $\mathrm{H}_{2} \mathrm{O}_{2}$ exposure [76,77]. A previous study reported that aluminum in the form of aluminum lactate intragastrically administered for 12 weeks could cause DNA fragmentation in the brain tissue of female Wistar rats when the genotoxic effect was assessed using agarose gel electrophoresis [78]. Using comet and MN tests, correlations were determined between the genotoxic damage caused by aluminum to the DNA of human lymphocytes and an increase in the dosage and exposure time [79]. The advantage of using the alkaline comet assay over the other in vitro methods is that it can detect lesions or damage to single- or double-stranded DNA as well as breaks in labile points in the DNA of single cells [80].

\subsubsection{Genetic Expression Assay Using RT-qPCR}

$B R C A 1$ is a genetic marker for breast cancer, and its role in the DNA damage repair mechanism has been demonstrated. Considering that it has undergone mutations, its expression is regulated by epigenetic modification and it is overexpressed in breast cancer [81-83]. Furthermore, the product of SCL11a2 has been identified as a divalent metal transporter gene [84-87]. The macrophage protein associated with natural resistance, Nramp, which is a product of SCL11a2, has recently been linked to aluminum transportation in different organisms $[88,89]$. Therefore, other molecular biological approaches must be applied in an attempt to establish this genetic relationship. Indeed, other researchers have obtained similar results. For example, cadmium reportedly induces DNA fragmentation and tumorigenesis, but not the expression of genes such as $b c l-x$ or MT-1 in Wistar rat testis and prostate [90]. Rodrigues-Peres et al. [91] found no ERBB2, C-MYC, and CCND1 gene instability when assessing the correlation between aluminum and genomic instability in cancerous human breast tissues and healthy tissues. Additionally, as previously reported, the changes were observed at extremely low or nanomolar concentrations of aluminum, with the ability to induce the expression of pro-inflammatory and pro-apoptotic genes. This may be related to some degree of genotoxicity $[92,93]$, as observed by our research group in the present study.

\section{Conclusions}

This study showed that aluminum chloride causes minimum-to-moderate hyperplastic (proliferative) intraductal cell proliferation and genotoxicity. Our results indicate that the BRCA1 product is not involved in the process of DNA damage repair and infer that the SCL11a2 product does not participate in aluminum transport under the proposed experimental conditions. 
Author Contributions: Performed the experiment and wrote the draft, A.M.G.-A.; Provided guidance for aluminum analysis, A.G.-Á.; Provided guidance for genomic evaluation, I.A.-C.; Provided guidance for toxicological assessment, A.B.-H.; Performed formal analysis, E.R.-B.; Performed experimental animal management, R.C.-R.; Performed statistical analysis, H.G.-R.; Provided guidance for histological analysis, J.G.L.-C.; Provided guidance for comet assays, K.L.R.-M.; Designed and supervised the study, H.A.-G. All authors have read and agreed to the published version of the manuscript.

Funding: This research was funded by Universidad de Sonora.

Acknowledgments: We acknowledge the individuals responsible for the laboratories where the experimental work was conducted.

Conflicts of Interest: The authors declare no conflict of interest. The funders had no role in the design of the study; in the collection, analyses, or interpretation of data; in the writing of the manuscript, or in the decision to publish the results.

\section{References}

1. López, F.F.; Cabrera, C.; Lorenzo, M.L.; López, M.C. Aluminium content of drinking waters, fruit juices and soft drinks:contribution to dietary intake. Sci. Total Environ. 2002, 92, 205-213. [CrossRef]

2. Darbre, P.D. Aluminium, antiperspirants and breast cancer. J. Inorg. Biochem. 2005, 99, 1912-1919. [CrossRef]

3. Kohara, I.; Tomoda, H.; Watanabe, S. New water-soluble metal working fluids additives from phosphonic acid derivatives for aluminum alloy materials. J. Oleo Sci. 2007, 56, 527-532. [CrossRef] [PubMed]

4. Yamamoto, S.; Tomoda, H.; Watanabe, S. Water-soluble metal working fluids additives derived from the esters of acid anhydrides with higher alcohols for aluminum alloy materials. J. Oleo Sci. 2007, 56, 463-469. [CrossRef] [PubMed]

5. Yokel, R.A.; Hicks, C.L.; Florenc, R.L. Aluminum bioavailability from basic sodium aluminum phosphate, an approved food additive emulsifying agent, incorporated in cheese. Food Chem. Toxicol. 2008, 46, 2261-2266. [CrossRef] [PubMed]

6. Gil, L.A.F.; Da Cunha, C.E.P.; Gustavo, M.S.G.; Salvarani, M.F.M.; Ronnie, A.; Lobato, A.F.C.; Mendonça, M.; Dellagostin, O.A.; Conceição, F.R. Production and evaluation of a recombinant chimeric vaccine against Clostridium botulinum neurotoxin types C and D. PLoS ONE 2013, 8, e69692. [CrossRef] [PubMed]

7. Güven, E.; Duus, K.; Laursen, I.; Højrup, P.; Houen, G. Aluminum hydroxide adjuvant differentially activates the three complement pathways with major involvement of the alternative pathway. PLoS ONE 2013, 8, e74445. [CrossRef] [PubMed]

8. Prozialeck, W.C.; Edwards, J.R.; Nebert, D.W. The vascular system as a target of metal toxicity. Toxicol. Sci. 2008, 102, 207-218. [CrossRef] [PubMed]

9. Tchounwou, P.B.; Yedjoum, C.G.; Patlolla, A.K.; Sutton, D.J. Heavy metal toxicity and the environment. EXS 2012, 101, 133-164.

10. Department of Health and Human Services. Division of Toxicology and Environmental Medicine. USA. 2008. Available online: https://www.atsdr.cdc.gov/toxprofiles/tp22.pdf (accessed on 14 April 2020).

11. Pikor, L.; Thu, K.; Vucic, E.; Lam, W. The detection and implication of genome instability in cancer. Cancer Metastasis Rev. 2013, 32, 41-352. [CrossRef]

12. Abbas, T.; Mignon, A.; Keaton, M.G.; Dutta, A. Genomic instability in cancer. Cold Spring Harb. Perspect. Biol. 2017, 5, a012914. [CrossRef] [PubMed]

13. Geraki, K.; Farquharson, M.J.; Bradley, D.A. Concentrations of Fe, $\mathrm{Cu}$ and $\mathrm{Zn}$ in breast tissue: A synchrotron XRF Study. Phys. Med. Biol. 2002, 47, 2327-2339. [CrossRef] [PubMed]

14. Al-Ebraheem, A.; Farquharson, M.J.; Ryan, E. The evaluations of biologically important trace metals in liver, kidney and breast tissue. Appl. Radiat. Isot. 2009, 7, 470-474. [CrossRef] [PubMed]

15. Silva, M.P.; Soave, D.F.; Riberiro-Silva, A.; Poletti, M.E. Trace elements as tumor biomarkers and prognostic factors in breast cáncer: A study throuh energy dispersive x-ray fluorescence. BMC Res. Notes 2012, 5, 194. [CrossRef] [PubMed]

16. Wang, Y.; Cheng, M.; Zhang, B.; Nie, F.; Jiang, H. Dietary supplementation of blueberry juice enhances hepatic expression of metallothionein and attenuates liver fibrosis in rats. PLoS ONE 2013, 8, e58659. [CrossRef]

17. Greger, J.L.; Bula, E.N.; Gum, E.T. Mineral metabolism of rats fed moderate levels of various aluminum compounds for short periods of time. J. Nutr. 1985, 115, 1708-1716. [CrossRef] 
18. Hubaux, R.; Becker-Santos, D.D.; Enfield, K.S.S.; La, R.D.E.; Lam, W.L.; Martinez, V.D. Molecular features in arsenic-induced lung tumors. Mol. Cancer 2013, 12, 2-11. [CrossRef]

19. García-Rodríguez, N.; Díaz de la Loza, M.C.; Anderson, B.; Monje-Casas, F.; Rothstein, R.; Wellinger, R.E. Impaired manganese metabolism causes mitotic misregulation. J. Biol. Chem. 2012, 287, 18717-18729. [CrossRef]

20. Diwan, B.A.; Kasprzak, K.S.; Anderson, L.M. Promotion of dimethylbenz[a]anthracene-initiated mammary carcinogenesis by iron in female Sprague-Dawley rats. Carcinogenesis 1997, 18, 1757-1762. [CrossRef]

21. Bobrowska, B.; Skrajnowska, D.; Tokarz, A. Effect of $\mathrm{Cu}$ supplementation on genomic instability in chemically-induced mammary carcinogenesis in the rat. J. Biomed. Sci. 2011, 18, 95. [CrossRef]

22. Rahim, F.; Jalali, A.; Tangestani, R. Breast cancer frequency and exposure to cadmium: A meta-analysis and systematic. Asian Pac. J. Cancer Prev. 2013, 14, 4283-4287. [CrossRef] [PubMed]

23. Darbre, P.D. Underarm, antiperspirants/deodorants and breast cancer. Breast Cancer Res. 2009, 11 (Suppl.3), S5. [CrossRef] [PubMed]

24. Lambert, V.; Boukhari, R.; Nacher, M.; Goullé, J.P.; Roudier, E.; Elguindi, W.; Laquerrière, A.; Carles, G. Plasma and urinary aluminum concentrations in severely anemic geophagous pregnant women in the bas Maroni region of French Guiana: A Case-Control Study. Am. J. Trop. Med. Hyg. 2010, 83, 1100-1105. [CrossRef]

25. Wang, N.; She, Y.; Zhu, Y.; Zhao, H.; Shao, B.; Sun, H.; Hu, C.; Li, Y. Effects of subchronic aluminum exposure on the reproductive function in female rats. Biol. Trace Elem. Res. 2012, 145, 382-387. [CrossRef]

26. Zhang, C.; Li, Y.; Wang, C.; Lv, R.; Song, T. Extremely low-frequency magnetic exposure appears to have no effect on pathogenesis of Alzheimer's disease in aluminum-overloaded rat. PLoS ONE 2013, 8, e17087. [CrossRef] [PubMed]

27. Zhu, Y.; Han, Y.; Zhao, H.; Li, J.; Hu, C.; Li, Y.; Zhang, Z. Suppressive effect of accumulated aluminum trichloride on the hepatic microsomal cytochrome P450 enzyme system in rats. Food Chem. Toxicol. 2013, 51, 210-214. [CrossRef]

28. Balasubramanyam, A.; Sailaja, N.; Mahboob, M.; Rahman, M.F.; Hussain, S.M.; Grover, P. In vivo genotoxicity assessment of aluminium oxide nanomaterials in rat peripheral blood cells using the comet assay and micronucleus test. Mutagenesis 2009, 24, 245-251. [CrossRef]

29. Hirata-Koizumi, M.; Fujii, S.; Ono, A.; Hirose, A.; Imai, T.; Ogawa, K.; Ema, M.; Nishikawa, A. Two-generation reproductive toxicity study of aluminium sulfate in rats. Reprod. Toxicol. 2011, 31, 219-230. [CrossRef]

30. Gullino, P.; Pettigrew, H.; Grantham, F.N. Nitrosomethylurea is a mammary gland carcinogen in rats. J. Natl. Cancer Inst. 1975, 54, 401-414.

31. Bobrowska-Korczak, B.; Skrajnowska, D.; Tokarz, A. The effect of dietary zinc-And polyphenols intake on DMBA-induced mammary tumorigenesis in rats. J. Biomed. Sci. 2012, 19, 43. [CrossRef]

32. Chou, Y.C.; Guzman, R.C.; Swanson, S.M.; Yang, J.; Lui, H.M.; Wu, V.; Nandi, S. Induction of mammary carcinomas by $N$-methyl- $N$-nitrosourea in ovariectomized rats treated with epidermal growth factor. Carcinogenesis 1999, 20, 677-684. [CrossRef] [PubMed]

33. Rees, S.L.; Panesar, S.; Steiner, M.; Fleming, A.S. The effects of adrenalectomy and corticosterone replacement on induction of maternal behavior in the virgin female rat. Horm. Behav. 2006, 49, 337-345. [CrossRef] [PubMed]

34. Norma Oficial Mexicana. NOM-033-ZOO-1995. Sacrificio Humanitario de los Animales Domésticos y Silvestres; SAGARPA: México D.F., Mexico, 1995.

35. Norma Oficial Mexicana. NOM-062-ZOO-1999. Especificaciones Técnicas Para la Producción, Cuidado y uso de los Animales de Laboratorio; SAGARPA: México D.F., Mexico, 1999.

36. European Medicines Agency (EMEA). Committee for Medicinal Products for Veterinary Use (CVMP). Recommendation on the Evaluation of the Benefit-Risk Balance of Veterinary Medicinal Products; European Medicines Agency: London, UK, 2009.

37. Food and Drug Administration (FDA). CFR_Code of Federal Regulations Title 21, Chapter I, Subchapter E, Part 511; Revised as of April 1; Food and Drug Administration: Silver Spring, MD, USA, 2014.

38. Perkin Elmer. Manual Operation of Equipment Microwave Furnance Model TITAN MPS; Perkin Elmer: Waltham, MD, USA, 2014. 
39. Bohrer, D.; Dessuy, M.B.; Kaizer, R.; Do Nascimento, P.C.; Schetinger, M.R.C.; Morsch, V.M.; Carvalho, L.M.; Garcia, S.C. Tissue digestion for aluminum determination in experimental animal studies. Anal. Biochem. 2008, 377, 120-127. [CrossRef]

40. Neiva, T.J.C.; Benedetti, A.L.; Tanaka, S.M.C.N.; Santos, J.I.; D’ Amico, E.A. Determination of serum aluminum, platelet aggregation and lipid peroxidation in hemodialyzed patients. Braz. J. Med. Biol. Res. 2002, 35, 345-350. [CrossRef] [PubMed]

41. Perkin Elmer. Manual Operation of Equipment Atomic Absorption Spectroscopy Model AAnalyst 400; Perkin Elmer: Waltham, MD, USA, 2012.

42. García-Alegría, A.M.; Gómez-Álvarez, A.; Anduro-Corona, I.; Burgos-Hernández, A.; Ruiz-Bustos, E.; Canett-Romero, R.; Astiazarán-García, H.F. Optimización de las condiciones analíticas ideales para cuantificar aluminio en tejidos de ratas Sprague Dawley, mediante la técnica de absorción atómica. Rev. Int. Contam. Ambient. 2017, 34, 7-24. [CrossRef]

43. García-Alegría, A.M.; Gómez-Álvarez, A.; Anduro-Corona, I.; Burgos-Hernández, A.; Ruiz-Bustos, E.; Canett-Romero, R.; Soto-Encinas, K.K.; Astiazarán-García, H.F. Validation of analytical method to quantify aluminum in tissues of Sprague Dawley rats by FAAS and GFAAS. Acta Univ. Multidiscip. Sci. J. 2017, 27, $22-35$.

44. García-Alegría, A.M.; Gómez-Álvarez, A.; Anduro-Corona, I.; Burgos-Hernández, A.; Ruiz-Bustos, E.; Canett-Romero, R.; Cáñez-Carrasco, M.G.; Astiazarán-García, H.F. Estimation of the expanded uncertainty of an analytical method to quantify aluminum in tissue of Sprague Dawley rats by FAAS and ETAAS. MAPAN J. Metrol. Soc. India 2017, 32, 131-141. [CrossRef]

45. Esendagli, G.; Canpinar, H.; Yilmaz, G.; Gunel-Ozcan, A.; Oguz-Guc, M.; Kansu, E.; Guc, D. Primary tumor cells obtained from MNU-induced mammary carcinomas show immune heterogeneity which can be modulated by low-efficiency transfection of CD40L gene. Cancer Biol. Ther. 2009, 8, 132-142. [CrossRef]

46. Hatton, C.S.R. Hematología: Diagnóstico y Tratamiento; El Manual Modern: México D.F., México, 2014.

47. García-Medina, S.; Razo-Estrada, C.; Galar-Martínez, M.; Cortéz-Barberena, E.; Gómez-Oliván, L.M.; Álvarez-González, I.; Madrigal-Bujaidar, E. Genotoxic and cytotoxic effects induced by aluminum in the lymphocytes of the common carp (Cyprinus carpio). Comp. Biochem. Physiol. Part C 2011, 153, 113-118. [CrossRef]

48. Pereira, S.; Cavalie, I.; Camilleri, V.; Gilbin, R.; Adam-Guillermin, C. Comparative genotoxicity of aluminium and cadmium in embryonic zebrafish cells. Mutat. Res. 2013, 750, 19-26. [CrossRef]

49. Singh, N.P.; Tice, R.R.; Stephensen, R.E.; Schneider, E. A microgel electrophoresis technique for the direct quantitation of DNA damage and repair in individual fibroblasts cultured on microscope slides. Mutat. Res. 1991, 252, 289-296. [CrossRef]

50. Olive, P.L.; Banáth, J.P.; Durand, R.E. Heterogeneity in radiation-induced DNA damage and repair in tumor and normal cells measured using the comet assay. Radiat. Res. 1990, 122, 86-94. [CrossRef] [PubMed]

51. Yáñez, L.; García-Nieto, E.; Rojas, E.; Carrizales, L.; Mejía, J.; Calderón, J.; Razo, I.; Díaz-Barriga, F. DNA damage in blood cells from children exposed to arsenic and lead in a mining area. Environ. Res. 2003, 93, 231-240. [CrossRef] [PubMed]

52. Chomczynski, P.; Sacchi, N. Single-step method of RNA isolation by acid guanidinium thiocyanate-phenol-chloroform extraction. Anal. Biochem. 1987, 162, 156-159. [CrossRef]

53. Desjardins, P.; Conklin, D. NanoDrop microvolume quantitation of nucleic acids. J. Vis. Exp. 2010, 45, e2565. [CrossRef]

54. Jacobs Protocol. Available online: http://www.openwetware.org/wiki/Jacobs:Protocol_RNA_Agarose_Gel (accessed on 14 April 2020).

55. Thompson, H.J.; Singh, M.; McGinley, J. Classification of premalignant and malignant lesions developing in the rat mammary gland after injection of sexually immature rats with 1-methyl-1-nitrosourea. J. Mammary Gland Biol. Neoplasia 2000, 5, 201-210. [CrossRef]

56. Perše, M.; Cerar, A.; Injac, R.; Štrukelj, B. N-methylnitrosourea induced breast cancer in rat, the histopathology of the resulting tumours and its Drawbacks as a model. Pathol. Oncol. Res. 2009, 15, 115-121. [CrossRef]

57. Türkez, H.; Yousef, M.I.; Geyikoglu, F. Propolis prevents aluminium-induced genetic and hepatic damages in rat liver. Food Chem. Toxicol. 2010, 48, 2741-2746. [CrossRef] 
58. Geyikoglu, F.; Türkez, H.; Bakir, T.O.; Cicek, M. The genotoxic, hepatotoxic, nephrotoxic, haematotoxic and histopathological effects in rats after aluminium chronic intoxication. Toxicol. Ind. Health 2012, 29, 780-791. [CrossRef]

59. Oogoshi, K.; Yanagi, S.; Moriyama, T.; Arachi, H. Accumulation of aluminum in cancers of the liver, stomach, duodenum and mammary glands of rats. J. Trace Elem. Electrolytes Health Dis. 1994, 8, 27-31.

60. Lee, R.; Woo, W.; Wu, B.; Kummer, A.; Duminy, H.; Xu, Z. Zinc accumulation in $N$-methyl- $N$-nitrosourea-induced rat mammary tumors is accompanied by an altered expression of ZnT-1 and metallothionein. Exp. Biol. Med. 2003, 228, 689-696.

61. Lee, S.; Simpson, M.; Nimmo, M.; Xu, Z. Low zinc intake suppressed $N$-methyl-N-nitrosourea-induced mammary tumorigenesis in Sprague Dawley rats. Carcinogenesis 2004, 25, 1879-1885. [CrossRef] [PubMed]

62. Lee, W.M.; Lua, S.; Medlineb, A.; Michael, C.; Archer, M.C. Susceptibility of lean and obese Zucker rats to tumorigenesis induced by $N$-methyl-N-nitrosourea. Cancer Lett. 2001, 166, 155-160. [CrossRef]

63. Sharma, R.; Kline, R.P.; Ed, X.; Wu, E.X.; Jose, K.; Katz, J.K. Rapid in vivo taxotere quantitative chemosensitivity response by 4.23 tesla sodium MRI and histo-immunostaining features in $N$-methyl- $N$-nitrosourea induced breast tumors in rats. Cancer Cell Int. 2005, 5, 26. [CrossRef] [PubMed]

64. Vegh, I.; Enríquez de Salamanca, R. Prolactin, TNF alpha and nitric oxide expression in nitroso- $N$-methylurea-induced-mammary tumours. J. Carcinog. 2007, 6, 18. [CrossRef]

65. Goss, P.E.; Strasser-Weipp, K.; Qi, S.; Hu, H. Effects of liarozole fumarate (R85246) in combination with tamoxifen on $\mathrm{N}$-methyl- $\mathrm{N}$-nitrosourea (MNU)-induced mammary carcinoma and uterus in the rat model. BMC Cancer 2007, 7, 26. [CrossRef]

66. Krishnan, P.; Yan, K.J.; Windler, D.; Tubbs, J.; Grand, R.; Li, B.D.L.; Aldaz, C.M.; McLarty, J.; Kleiner-Hancock, H.E. Citrus auraptene suppresses cyclin D1 and significantly delays $N$-methyl nitrosourea induced mammary carcinogenesis in female Sprague-Dawley rats. BMC Cancer 2009, 9, 259. [CrossRef]

67. Faustino-Rocha, A.I.; Silva, A.; Gabriel, J.; Teixeira-Guedes, C.I.; Lopes, C.; Gil da Costa, R.; Gama, A.; Ferreira, R.; Oliveira, P.A.; Ginja, M. Ultrasonographic, thermographic and histologic evaluation of MNU-induced mammary tumors in female Sprague-Dawley rats. Biomed. Pharmacother. 2013, 67, 771-776. [CrossRef]

68. Rajmani, R.S.; Doley, J.; Singh, P.K.; Kumar, R.; Barathidasan, R.; Kumar, P.; Verma, P.C.; Tiwari, A.K. Induction of mammary gland tumour in rats using $N$-methyl- $N$-nitroso urea and their histopathology. Indian J. Vet. Pathol. 2011, 35, 142-146.

69. Mughal, A.; Vikram, A.; Ramarao, P.; Jena, G.B. Micronucleus and comet assay in the peripheral blood of juvenile rat: Establishment of assay feasibility, time of sampling and the induction of DNA damage. Mutat. Res. 2010, 700, 86-94. [CrossRef]

70. Balasubramanyam, A.; Sailaja, N.; Mahboob, M.; Rahman, M.F.; Misra, S.; Hussain, S.M.; Grover, P. Evaluation of genotoxic effects of oral exposure to Aluminum oxide nanomaterials in rat bone marrow. Mutat. Res. 2009, 676, 41-47. [CrossRef] [PubMed]

71. Klien, K.; Godnić-Cvar, J. Genotoxicity of metals nanoparticules: Focus on in vivo studies. Arh. Hig. Rada Toksikol. 2012, 63, 133-145. [CrossRef] [PubMed]

72. Türkez, H.; Geyikoglu, F.; Colak, S. The protective effect of boric acid on aluminum-induced hepatotoxicity and genotoxicity in rats. Turk. J. Biol. 2011, 35, 293-301.

73. Türkez, H.; Geyikoglu, F.; Tatar, A. Borax counteracts genotoxicity of aluminum in rat liver. Toxicol. Ind. Health 2012, 29, 775-779. [CrossRef]

74. AL-Obaidy, O.R.K.; Al-Samarrai, A.S.M.; Al-Samarrai, Y.S.Y. Genotoxicity of aluminum chloride $\left(\mathrm{AlCl}_{3}\right)$ on the albino rat Rattus norvegicus. Iraqi J. Cancer Med. Genet. 2016, 9, 18-24.

75. Banasik, A.; Lankoff, A.; Piskulak, A.; Adamowska, K.; Lisowsk, H.; Wojcik, A. Aluminium-induced micronuclei and apoptosisin human peripheral blood lymphocytes treated during different phases of the cell cycle. Environ. Toxicol. 2005, 20, 402-406. [CrossRef]

76. Ayala, M.C.; Hernández, Y.G.; Piñeiro, J.C.G.; González, E.P. Uso del ensayo cometa para evaluar el efecto de la temperatura sobre la reparación del daño genético inducido por peróxido de hidrógeno y la radiación ultravioleta A en células sanguíneas humanas. Acta Farm. Bonaerense. 2004, 23, 277-284. 
77. Stanić, D.; Plećaš-Solarović, B.; Petrović, J.; Bogavac-Stanojević, N.; Sopić, M.; Kotur-Stevuljević, J.; Ignjatović, S.; Pešić, V. Hydrogen peroxide-induced oxidative damage in peripheral blood lymphocytes from rats chronically treated with corticosterone: The protective effect of oxytocin treatment. Chem. Biol. Interact. 2016, 256, 134-141. [CrossRef]

78. Kumar, V.; Bal, A.; Gill, K.D. Aluminium-induced oxidative DNA damage recognition and cell-cycle disruption in different regions of rat brain. Toxicology 2009, 264, 137-144. [CrossRef]

79. Lankoff, A.; Banasik, A.; Duma, A.; Ochniak, E.; Lisowska, H.; Kuszewski, T.; Góźdź, S.; Wojcik, A. A comet assay study reveals that aluminium induces DNA damage and inhibits the repair of radiation-induced lesions in human peripheral blood lymphocytes. Toxicol. Lett. 2006, 161, 27-36. [CrossRef]

80. Hartmann, A.; Schumacher, M.; Plappert-Helbig, U.; Lowe, P.; Suter, W.; Mueller, L. Use of the alkaline in vivo comet assay for mechanistic genotoxicity investigations. Mutagenesis 2004, 19, 51-59. [CrossRef] [PubMed]

81. Wu, J.; Lu, L.Y.; Yu, X. The role of BRCA1 in DNA damage response. Protein Cell 2010, 1, 117-123. [CrossRef]

82. Li, M.L.; Greenberg, R.A. Links between genome integrity and BRCA1 tumor suppression. Trends Biochem. Sci. 2012, 37, 418-424. [CrossRef] [PubMed]

83. Savage, K.I.; Harkin, D.P. BRCA1, a 'complex' protein involved in the maintenance of genomic stability. FEBS J. 2015, 282, 630-646. [CrossRef] [PubMed]

84. Jamieson, S.E.; White, J.K.; Howson, J.M.M.; Pask, R.; Smith, A.N.; Brayne, C.; Evanse, J.G.; Xuereb, J.; Cairns, N.J.; Rubinszteina, D.C.; et al. Candidate gene association study of solute carrier family 11a members 1 (SLC11A1) and 2 (SLC11A2) genes in Alzheimer's disease. Neurosci. Lett. 2005, 374, 124-128. [CrossRef] [PubMed]

85. Mims, M.P.; Prchal, J.T. Divalent metal transporter 1. Hematology 2005, 10, 339-345. [CrossRef]

86. Iolascon, A.; d'Apolito, M.; Servedio, V.; Cimmino, F.; Piga, A.; Camaschella, C. Microcytic anemia and hepatic iron overload in a child with compound heterozygous mutations in DMT1 (SCL11A2). Blood 2006, 107, 349-354. [CrossRef]

87. Salazar, J.; Mena, N.; Hunot, S.; Prigent, A.; Alvarez-Fischer, D.; Arredondo, M.; Duyckaerts, C.; Sazdovitch, V.; Zhao, L.; Garrick, L.M.; et al. Divalent metal transporter 1 (DMT1) contributes to neurodegeneration in animal models of Parkinson's disease. Proc. Natl. Acad. Sci. USA 2008, 105, 18578-18583. [CrossRef]

88. Xia, J.; Yamaji, N.; Kasai, T.; Ma, J.F. Plasma membrane-localized transporter for aluminum in rice. Proc. Natl. Acad. Sci. USA 2010, 107, 18381-18385. [CrossRef] [PubMed]

89. Vanduyn, N.; Settivari, R.; LeVora, J.; Zhou, S.; Unrine, J.; Nass, R. The metal transporter SMF-3/DMT-1 mediates aluminum-induced dopamine neuron degeneration. J. Neurochem. 2013, 124, 147-157. [CrossRef] [PubMed]

90. Xu, G.; Zhou, G.; Jin, T.; Zhou, T.; Hammarström, S.; Bergh, A.; Nordberg, G. Apoptosis and p53 gene expression in male reproductive tissues of cadmium exposed rats. Biometals 1998, 12, 131-139. [CrossRef] [PubMed]

91. Rodrigues-Peres, R.M.; Cadore, S.; Febraio, S.; Heinrich, J.K.; Serra, K.P.; Derchain, S.F.M.; Vassallo, J.; Sarian, L.O. Tissue aluminum concentration does not affect the genomic stability of ERBB2, C-MYC, and CCND1 genes in breast cancer. Biol. Trace Elem. Res. 2013, 154, 345-351. [CrossRef] [PubMed]

92. Lukiw, W.J.; Percy, M.E.; Kruck, T.P. Nanomolar aluminum induces pro-inflammatory and pro-apoptotic gene expression in human brain cells in primary culture. J. Inorg. Biochem. 2005, 99, 1895-1898. [CrossRef] [PubMed]

93. Pogue, A.I.; Lukiw, W.J. Aluminum, the genetic apparatus of the human CNS and Alzheimer's disease (AD). Morphologie 2016, 100, 56-64. [CrossRef]

(C) 2020 by the authors. Licensee MDPI, Basel, Switzerland. This article is an open access article distributed under the terms and conditions of the Creative Commons Attribution (CC BY) license (http://creativecommons.org/licenses/by/4.0/). 